\title{
IMPLEMENTASI EKSPERIMEN “PENGERUH TINGGI PARA- PARA TERHADAP PRODUKSI TANAMAN TOMAT (Lycopersicum esculentum Mill)" PADA PEMBELAJARAN HORTIKULTURA
}

\author{
*) Dewa Nyoman Oka, ${ }^{* *)}$ Ida Bagus Arnyana, ${ }^{* \star}$ ) I Gede Sudirgayasa \\ $\left.{ }^{\star}\right),{ }^{* \star}$ JJurusan Pendidikan Bilogi, FPMIPA, IKIP Saraswati \\ **)Jurusan Biologi FMIPA UNDIKSHA
}

\begin{abstract}
Abstrak: Tujuan penelitian ini adalah untuk mengetahui (1) pengaruh tinggi para-para terhadap produksi tanaman tomat; (2) relevansi implementasi model ekspemerimen ini pada proses pembelajaran hortikultura. Jenis penelitian ini adalah eksperimental, dengan menggunakan rancangan acak lengkap. Sampel penelitian dibagi menjadi dua kelompok, yaitu kelompok kontrol $\left(P_{0}\right)$ yang tidak diberi para-para dan kelompok eksperimen $\left(\mathrm{P}_{1}, \mathrm{P}_{2}, \mathrm{P}_{3}\right.$ dan $\left.\mathrm{P}_{4}\right)$ yang diberi perlakuan berupa para-para dari bambu dengan tinggi masing-masing $40 \mathrm{~cm}, 60 \mathrm{~cm}, 80 \mathrm{~cm}$ dan $100 \mathrm{~cm}$. Jumlah ulangan dilakukan sebanyak empat kali. Jumlah sampel pada masing-masing perlakuan 3 tanaman. Jumlah total tanaman tomat yang dipakai sampel adalah $5 \times 4 \times 3$ tanaman $=$ 60 tanaman. Data yang dianalisis adalah data berat basah buah tomat. Hasil analisis uji normalitas dan homogenitas menunjukkan data terdistribusi normal dan homogen. Sedangkan hasil analisis uji anova menunjukan adanya perbedaan yang signifikan. Selanjutnya hasil analisis uji lanjut dengan uji LSD atau uji BNT, menunjukan bahwa ada perbedaan yang signifikan antara berat basah buah tomat berdasarkan perlakuan di mana hasil terbaik diperoleh pada tanaman tomat dengan perlakuan $\mathrm{P}_{4}$ yaitu penanaman dengan para-para setinggi $100 \mathrm{~cm}$. Eksperimen ini sangat relevan untuk diimplentasikan pada proses pembelajaran hortikultura, mengingat eksperimen ini mampu mengembangkan potensi dan kreativitas mahasiswa serta lamanya eksperimen relatif memadai yaitu 120 hari atau 17 minggu.
\end{abstract}

Kata kunci: tinggi para-para, produksi, tanaman tomat, hortikultura.

Abstract: This experimental research, which used complete randomized design was conducted to identify the influence of para-para's height on the production of tomatoes and the relevance of this experimental model to horticulture learning process. The research samples were divided into two groups, the control group $\left(P_{0}\right)$ which was not given the para-para and the experimental group $\left(P_{1}, P_{2}, P_{3}\right.$ and $\left.P_{4}\right)$ which were given the para-para made of bamboo that were $40 \mathrm{~cm}, 60 \mathrm{~cm}, 80 \mathrm{~cm}$ and $100 \mathrm{~cm}$ in height. The number of tests was carried out four times and the number of samples in each treatment was 3 plants. The number of tomato plants used as the samples was $5 \times 4 \times 3$ plants $=$ 60 plants. The data were the wet weight of the tomatoes whose normality and homogeneity were analyzed. The result of the analysis showed that the data were normally distributed and homogeneous while the results of the ANOVA test showed significant differences. Furthermore, the results of further test analysis with LSD test or BNT test showed that there was a significant difference between the wet weight of 
tomatoes based on the treatment on which the best results were tomato plants with P4 treatment that was planting with as high as $100 \mathrm{~cm}$ of para-para. This experiment was very relevant to be implemented in the horticulture learning process considering that the experiment was able to develop the potential and creativity of university students. In addition, the duration of the experiment was relatively adequate, i.e. 120 days or 17 weeks.

Keywords: the height of para-para, production, tomato plants, horticulture.

\section{PENDAHULUAN}

Tanaman tomat (Lycopersicum esculentum Mill) adalah jenis sayuran buah tahunan, yang dapat ditanam di tanah dataran rendah ataupun dataran tinggi. Menurut asalnya, tanaman ini konon berasal dari benua Eropa, yang telah beratus-ratus tahun menyesuaikan diri di alam Indonesia. Tanaman ini berbentuk perdu, tinggi batangnya dua meter atau lebih, mempunyai batang lunak dan bulat. Batang tanaman muda mudah patah sedangkan setelah tua menjadi keras hampir berkayu, serta bercabang lebat dan seluruh permukaan batangnya berbulu halus. Daun tanaman umumnya lebar bersirip, berbulu dan berwarna hijau. Buah tomat umumnya berbentuk bulat atau bulat pipih dan ada pula yang berbentuk oval. Warna buah yang masak merah merekah, yang muda berwarna hijau. Daging buahnya banyak mengandung air dan menyimpan biji yang banyak jumlahnya. Buah tomat yang masak banyak digemari orang rasanya segar, manis dan sedikit asam.

Tomat sangat bermanfaat bagi tubuh karena banyak mengandung vitamin dan mineral yang diperlukan untuk pertumbuhan dan kesehatan, di antaranya adalah sebagai sumber vitamin $A$ yang penting bagi kesehatan mata, serta vitamin $\mathrm{C}$ yang berfungsi sebagai antioksidan. Buah tomat merupakan sumber mineral karena tomat mengandung $\mathrm{Fe}$ (zat besi) yang berguna untuk pembentukan sel darah merah atau hemoglobin, tomat juga mengandung serat untuk membantu penyerapan makanan dalam pencernaan serta mengandung potassium yang bermanfaat untuk menurunkan tekanan darah tinggi. Penggunaannya semakin luas, karena selain dikonsumsi sebagai tomat segar dan untuk bumbu masakan, juga dapat diolah lebih lanjut sebagai bahan baku industri makanan seperti sari buah dan saus tomat. Tomat adalah sumber vitamin, mineral, dan antioksidan yang sangat baik yang membantu mengendalikan kanker, serta meningkatkan kesehatan manusia secara umum (Ogundare, 2015).

Buah tomat saat ini merupakan salah satu komoditas hortikultura yang bernilai ekonomi tinggi dan masih memerlukan penanganan serius, terutama dalam hal peningkatan hasil dan kualitas buahnya. Apabila dilihat dari rata-rata produksinya, ternyata tomat di Indonesia masih rendah, yaitu 6,3 ton/ha jika dibandingkan dengan negara-negara Taiwan, Saudi Arabia dan India yang berturut-turut 21 ton/ha, 13,4 ton/ha dan 9,5 ton/ha. Mengingat prospek pemasaran buah tomat di masa yang akan datang cukup cerah baik dalam memenuhi kebutuhan lokal maupun kebutuhan nasional dan ekspor. Prospek ini tentunya harus didukung oleh produksi yang tinggi dan berkualitas. Produksi tinggi dan 
berkualitas tidak terlepas dari teknis budidaya. Teknis budidaya yang harus diperhatikan salah satunya adalah pemeliharaan tanaman di antaranya pemasangan para-para pada tanaman tomat

Batang tanaman tomat tidak mampu tegak dengan kokoh terutama setelah berbuah. Oleh karena itu untuk memperoleh hasil tomat yang baik maka setiap batang tanaman tomat perlu dipasang para-para sebagai tempat tumbuh tegak ke atas. Keuntungan yang diperoleh dalam penggunaan para-para adalah mudah dirawat, bebas mendapatkan penyinaran matahari yang cukup, bunga tidak rusak, buah tidak kotor dan terhindar dari serangan hama (Setiawan, 1999). Selain itu, keuntungan pemasangan para-para yaitu tanaman tumbuh tegak, memperbaiki penyebaran daun dan tunas, mempermudah penyemprotan pestisida maupun penyiangan gulma dan pemupukan (Rukmana, 1994). Para-para memungkinkan tajuk tanaman tersebar lebih terbuka sehingga cahaya lebih merata terdistiribusi pada permukaan daun sehingga lebih banyak organ tanaman yang menjalankan proses fotosintesis (Nabuanaa, 2016).

Terkait dengan dunia pendidikan. Permasalahan penting yang dihadapi oleh dunia pendidikan sampai saat sekarang ini adalah bagaimana mengupayakan membangun pemahaman dan memberdayakan kemampuan berpikir. Beberapa usaha yang telah dilakukan oleh pemerintah adalah peningkatan sarana dan prasarana pendidikan, memperbanyak penyediaan buku di perpustakaan, serta mengadakan penataran-penataran bagi para dosen. Pemerintah juga telah menyediakan peluang kepada mahasiswa untuk mencapai pemahaman yang lebih baik dengan cara meningkatkan kualifikasi dosen, serta revisi kurikulum. Usaha-usaha tersebut telah dilakukan secara berkala dan intensif, tetapi permasalahan tersebut belum sepenuhnya terpecahkan. Hal ini berarti masih tetap diperlukan usaha-usaha yang lebih inovatif untuk pelaksanaan reformasi pendidikan.

Berkaitan dengan pendidikan dan pembelajaran, pembelajaran matakuliah hortikultura memiliki karakteristik yang berbeda dengan matakuliah yang lain. Oleh sebab itu guru/dosen matakuliah ini diharapkan mampu kreatif dan jeli dalam memilih dan menggunakan pendekatan, strategi, dan metode dalam pembelajaran hortikultura. Semua ini disebabkan proses interaksi dalam pembelajaran diharapkan mengikuti perkembangan proses pembelajaran paradigma baru. Paradigma baru tersebut yang lebih mengedepankan pendekatan kontekstual (contextual teaching and learning) artinya lingkungan diharapkan dapat dijadikan sebagai sumber belajar, belajar bersama (cooperative learning), pembelajaran yang berpusat pada siswa (student centered learning), pembelajaran aktif (active learning) dan memberikan pengalaman belajar yang bermakna bagi siswa.

Salah satu capaian pembelajaran matakuliah hortikultura di program studi pendidikan biologi IKIP Saraswati adalah mahasiswa mampu mengaplikasikan pengetahuan dasar hortikultura dalam bercocok tanam tanaman hortikutura dan membuat taman. Untuk dapat mencapai capaian pembelajaran tersebut mahasiswa diharapkan memiliki beberapa kemampuan. Seperti kemampuan mengidentifikasi faktor-faktor penting yang berpengaruh dalam pengusahaan tanaman hortikultura. Kemampuan ini hanya dapat dimiliki kalau mahasiswa terlibat aktif dalam proses pembelajaran. Dalam pembelajaran aktif peserta didik tidak lagi ditempatkan dalam posisi pasif sebagai penerima bahan ajar yang diberikan guru/dosen, tetapi sebagai subjek yang aktif 
melakukan proses berpikir, mencari, mengolah, mengurai, menggabung, menyimpulkan, dan menyelesaikan masalah (Hanafiah, 2009).

Experimental learning sangat sesuai untuk pembelajaran hortikultura, karena mampu memberikan kondisi belajar yang mengembangkan kemampuan berfikir dan kreativitas secara optimal. Mahasiswa diberi kesempatan untuk menyusun sendiri konsep dalam struktur kognitifnya yang selanjutnya dapat diaplikasikan dalam kehidupannya. Penggunaan metode eksperimen ini mempunyai tujuan agar mahasiswa mampu dan menemukan sendiri berbagai jawaban atau persoalan yang dihadapi dengan melakukan percobaan sendiri. Selain itu mahasiswa dapat terlatih dalam cara berfikir yang ilmiah. Dengan eksperimen mahasiswa menemukan bukti kebenaran dan teori sesuatu yang sedang dipelajari (Mulyani, 2015). Pada exsperimental learning (belajar berdasarkan pengalaman konkrit), siswa akan melakukan diskusi dengan teman, yang selanjutnya akan diperoleh ide dan konsep baru. Oleh karena itu, belajar dipandang sebagai proses penyusunan pengetahuan dari pengalaman konkrit, aktivitas kolaboratif, dan refleksi serta interpretasi (Haymembat, 2011).

Permasalahan

yang melatarbelakangi penelitian ini adalah belum diketahui pengaruh ketinggian para-para yang tepat, yang dapat meningkatkan produksi tanaman tomat dan kurangnya variasi model eksperimen yang dapat diimplementasikan dalam proses pembelajaran hortikultura. Tujuan yang ingin dicapai dalam penelitian ini adalah untuk mengetahui (1) apakah para-para dapat meningkatkan produksi tomat?; (2) Apakah model ekperimerimen ini cukup relevan diimplementasikan dalam proses pembelajaran hortikultura?

\section{METODE}

Jenis penelitian ini adalah eksperimental, dengan menggunakan rancangan acak lengkap atau Fully Randomized Design. Pada penelitian ini sampel penelitian dibagi menjadi dua kelompok, yaitu kelompok kontrol $\left(\mathrm{P}_{0}\right)$ yang tidak diberi para-para dan kelompok eksperimen $\left(P_{1}, P_{2}, P_{3}\right.$ dan $\mathrm{P}_{4}$ ) yang diberi perlakuan berupa parapara dari bambu dengan tinggi yang berbeda-beda. Perlakuan yang diberikan pada kelompok eksperimen ada empat kelompok, yaitu $P_{1}$ diberi para-para setinggi $40 \mathrm{~cm}, \mathrm{P}_{2}$ diberi parapara setinggi $60 \mathrm{~cm}, \mathrm{P}_{3}$ diberi para-para setinggi $80 \mathrm{~cm}$, dan $\mathrm{P}_{4}$ diberi para-para setinggi $100 \mathrm{~cm}$. Jumlah ulangan dilakukan sebanyak empat kali. Jumlah total perlakuan adalah $5\left(\mathrm{P}_{0}, \mathrm{P}_{1}, \mathrm{P}_{2}, \mathrm{P}_{3}\right.$ dan $\mathrm{P}_{4}$ ), jumlah sampel pada masingmasing perlakuan 3 tanaman. Jadi jumlah tanaman dalam satu kali percobaan adalah $5 \times 3$ tanaman $=15$ tanaman. Karena jumlah ulangan adalah 4 kali ulangan maka jumlah seluruh sampel dalam penelitian ini adalah $4 \times 15$ tanaman $=60$ tanaman . Populasi dalam penelitian ini adalah tanaman tomat varietas mutiara yang disemaikan dari biji hasil produksi Riawan Tani Belitar - Indonesia, yang diasumsikan memiliki sifat fisik dan genotif yang sama.

Data yang diperoleh berupa berat basah buah tomat yang telah masak yang dipetik sebanyak 3 kali mulai dari umur 102 hari sampai umur 120 hari. Hasil penimbangan berat basah buah tomat lalu direkap, hasil rekapitulasi itu diuji normalitas dan homogenitasnya. Uji normalitas dilakukan dengan menggunakan statistik Kolmogorov-Smirnov dan Shapiro-Wilk. Sedangkan uji homogenitas dilakukan dengan uji Levene. Tarap signifikansi (a) ditetapkan 0,05. Kriteria uji normalitas dan homogenitas yang digunakan adalah apabila bilangan signifikansi (sig.) lebih besar dari pada taraf signifikansi ( $\alpha$ ) maka bilangan statistik yang diperoleh tidak signifikan, artinya 
data sampel berasal dari populasi yang berdistribusi normal. Begitu juga sebaliknya. Jika persyaratan normalitas dan homogenitas telah terpenuhi baru diadakan analisis parametrik dengan uji anova. Jika ada perbedaan yang signifikan, maka perlu dilakukan uji lanjut untuk mengetahui kelompok perlakuan yang mana saja yang berbeda nyata. Uji lanjut dilakukan dengan uji LSD atau uji BNT.

\section{HASIL DAN PEMBAHASAN}

Data dikumpulkan dengan menimbang buah tomat yang telah masak yang dipetik sebanyak 3 kali mulai tanaman umur 102 hari sampai umur 120 hari. Hasil penimbangan berat basah buah tomat pada panen pertama, kedua dan ketiga direkap dan dirata-ratakan selanjutnta dimasukan pada

Tabel

Tabel 1. Rata-rata produksi berat basah buah tomat pada panen I, II, dan III (gram)

\begin{tabular}{llcccc}
\hline & \multicolumn{5}{c}{ PERLAKUAN } \\
\cline { 2 - 6 } ULANGAN $(\mathrm{N})$ & \multicolumn{1}{c}{$\mathrm{P} 0$} & $\mathrm{P} 1$ & $\mathrm{P} 2$ & $\mathrm{P} 3$ & $\mathrm{P4}$ \\
\cline { 2 - 6 } & \multicolumn{1}{c}{$(0 \mathrm{~cm})$} & $(40 \mathrm{~cm})$ & $(60 \mathrm{~cm})$ & $(80 \mathrm{~cm})$ & $(100 \mathrm{~cm})$ \\
\hline I & 31.5 & 58.1 & 67.4 & 84.3 & 154.5 \\
II & 47.7 & 48.5 & 61.2 & 100.8 & 146.7 \\
III & 52.8 & 56.6 & 63.7 & 75.6 & 125.7 \\
IV & 36.3 & 40.1 & 63.6 & 69.7 & 106.1 \\
TOTAL & 168.3 & 203.3 & 255.9 & 330.4 & 533 \\
RATA-RATA & 42.08 & 50.83 & 63.98 & 82.60 & 133.25 \\
\hline
\end{tabular}

Berdasarkan table 1 di atas dapat dilukiskan rata-rata produksi berat basah tomat pada masing-masing perlakuan seperti yang tampak pada Gambar 1.

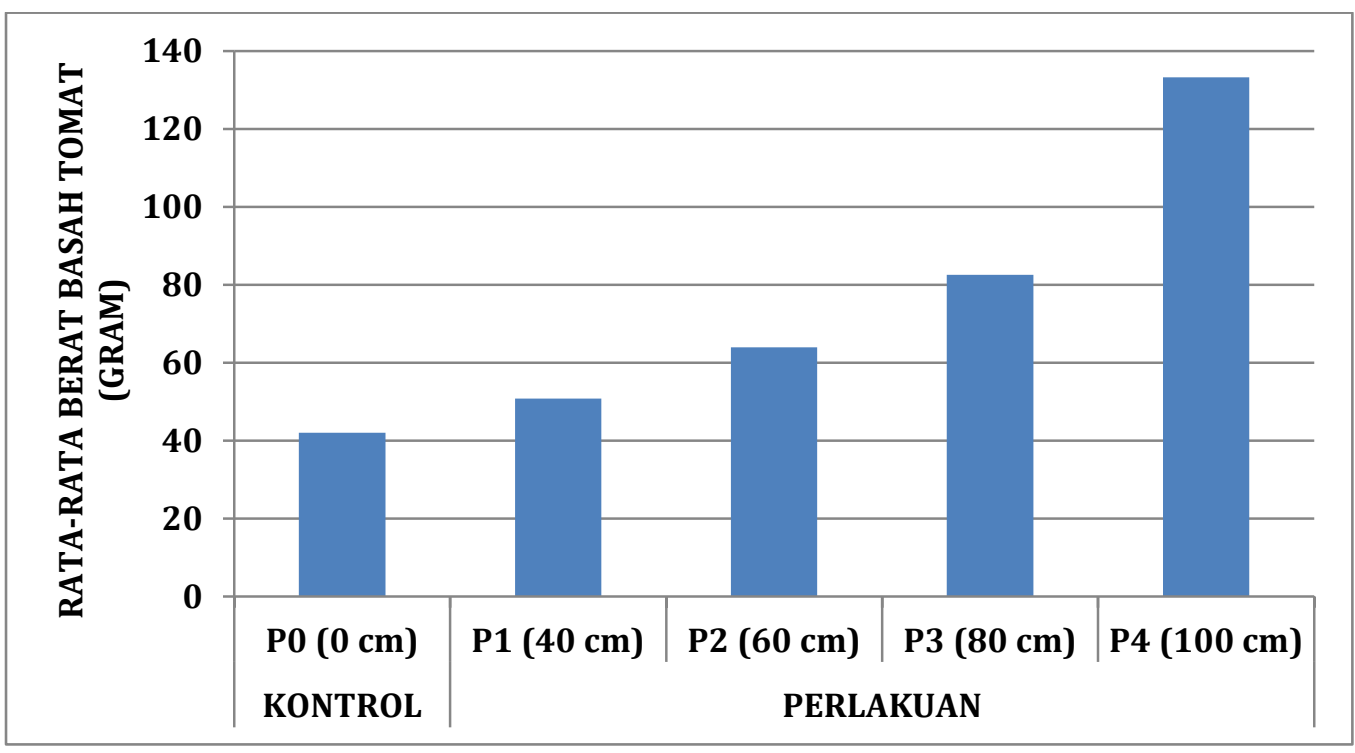

Gambar 1. Rata-rata berat basah tomat pada masing-masing perlakuan 


\section{Uji Normalitas dan Homogenitas}

Normalitas data produksi berat basah tomat diuji dengan Shapiro-Wilk. Sedangkan homogenitasnya diuji dengan uji Leven. Hasil analisis normalitas dan homogenitas data disajikan pada Tabel 2 dan Tabel 3.

\section{Tabel 2. Uji normalitas Shapiro-wilk}

\begin{tabular}{llll}
\hline Perlakuan & Shapiro-Wilk & & \\
\cline { 2 - 4 } & Statistic & Df & Sig. \\
\hline P0 & 0.937 & 4 & 0.635 \\
P1 & 0.910 & 4 & 0.485 \\
P2 & 0.931 & 4 & 0.602 \\
P3 & 0.948 & 4 & 0.702 \\
P4 & 0.947 & 4 & 0.698 \\
\hline
\end{tabular}

Berdasarkan hasil uji normalitas Shapiro-Wilkpa databel 2 dapat dilihat bahwa seluruh hasil pengujian menunjukkan sig. yang lebih besar dari
0,05 . Ini artinya seluruh data terdistribusi normal. Selanjutnya hasil uji homogenitas varian dapat dilihat pada tabel 3 berikut.

Tabel 3. Uji homogenitas Leven

\begin{tabular}{llll}
\hline $\begin{array}{l}\text { Levene } \\
\text { Statistic }\end{array}$ & df1 & df2 & Sig. \\
\hline 4.390 & 4 & 15 & 0.107 \\
\hline
\end{tabular}

Dari table 3 dapat kita ketahui bahwa berdasarkan hasil uji Levene Statistik nilai sig. menunjukkan nilai 0.107 yang lebih besar dari taraf signifikansi yang telah ditentukan yaitu sebesar 0,05 . Ini artinya varian data penelitian homogen. Dengan demikian uji anova bisa dilanjutkan. Adapun hasil uji Anova dirangkum sesuai pada Tabel 4.

Tabel 4. Uji anova

\begin{tabular}{|c|c|c|c|c|c|}
\hline & Sum of Squares & $\mathrm{Df}$ & Mean Square & $\mathrm{F}$ & Sig. \\
\hline $\begin{array}{l}\text { Between } \\
\text { Groups }\end{array}$ & 20959.297 & 4 & 5239.824 & 31.510 & 0.000 \\
\hline Within Groups & 2494.332 & 15 & 166.289 & & \\
\hline Total & 23453.630 & 19 & & & \\
\hline
\end{tabular}

Berdasarkan hasil uji anova, dapat dilihat bahwa nilai $F$ hitung sebesar 31.510 dengan sig. sebesar 0,000 yang jauh lebh kecil dari taraf signifikansi yang telah ditentukan sebesar 0.05 . Ini artinya secara umum terdapat perbedaan yang signifikan antara berat basah buah tomat berdasarkan perlakuan. Karena adanya perbedaan yang signifikan, maka perlu 
dilakukan uji lanjut untuk mengetahui kelompok perlakuan yang mana saja yang berbeda nyata. Uji lanjut dilakukan dengan uji LSD atau uji BNT. Adapun hasil uji lanjut ditunjukkan dalamTabel 5

Tabel 5. Uji LSD

\begin{tabular}{|c|c|c|c|c|c|c|}
\hline \multirow{2}{*}{$\begin{array}{c}\text { (I) } \\
\text { Perlakuan }\end{array}$} & \multirow{2}{*}{$\begin{array}{c}\text { (J) } \\
\text { Perlakuan }\end{array}$} & \multirow{2}{*}{$\begin{array}{c}\text { Mean } \\
\text { Difference (I-J) }\end{array}$} & \multirow[b]{2}{*}{ Std. Error } & \multirow[b]{2}{*}{ Sig. } & \multicolumn{2}{|c|}{$95 \%$ Confidence Interval } \\
\hline & & & & & $\begin{array}{l}\text { Lower } \\
\text { Bound }\end{array}$ & $\begin{array}{l}\text { Upper } \\
\text { Bound }\end{array}$ \\
\hline \multirow[t]{5}{*}{ P0 } & P0 & & & & & \\
\hline & $\mathrm{P} 1$ & -8.75000 & 9.11836 & .352 & -28.1853 & 10.6853 \\
\hline & $\mathrm{P} 2$ & $-21.90000^{*}$ & 9.11836 & .030 & -41.3353 & -2.4647 \\
\hline & P3 & $-40.52500^{*}$ & 9.11836 & .000 & -59.9603 & -21.0897 \\
\hline & $\mathrm{P} 4$ & $-91.17500^{*}$ & 9.11836 & .000 & -110.6103 & -71.7397 \\
\hline \multirow[t]{5}{*}{ P1 } & $\mathrm{PO}$ & 8.75000 & 9.11836 & .352 & -10.6853 & 28.1853 \\
\hline & $\mathrm{P} 1$ & & & & & \\
\hline & $\mathrm{P} 2$ & -13.15000 & 9.11836 & .170 & -32.5853 & 6.2853 \\
\hline & P3 & $-31.77500^{\star}$ & 9.11836 & .003 & -51.2103 & -12.3397 \\
\hline & $\mathrm{P} 4$ & $-82.42500^{*}$ & 9.11836 & .000 & -101.8603 & -62.9897 \\
\hline \multirow[t]{5}{*}{ P2 } & $\mathrm{PO}$ & $21.90000^{*}$ & 9.11836 & .030 & 2.4647 & 41.3353 \\
\hline & $\mathrm{P} 1$ & 13.15000 & 9.11836 & .170 & -6.2853 & 32.5853 \\
\hline & $\mathrm{P} 2$ & & & & & \\
\hline & P3 & -18.62500 & 9.11836 & .059 & -38.0603 & .8103 \\
\hline & $\mathrm{P} 4$ & $-69.27500^{*}$ & 9.11836 & .000 & -88.7103 & -49.8397 \\
\hline \multirow[t]{5}{*}{ P3 } & $\mathrm{PO}$ & $40.52500^{*}$ & 9.11836 & .000 & 21.0897 & 59.9603 \\
\hline & $\mathrm{P} 1$ & $31.77500^{*}$ & 9.11836 & .003 & 12.3397 & 51.2103 \\
\hline & $\mathrm{P} 2$ & 18.62500 & 9.11836 & .059 & -.8103 & 38.0603 \\
\hline & P3 & & & & & \\
\hline & $\mathrm{P} 4$ & $-50.65000^{*}$ & 9.11836 & .000 & -70.0853 & -31.2147 \\
\hline \multirow[t]{5}{*}{ P4 } & PO & $91.17500^{*}$ & 9.11836 & .000 & 71.7397 & 110.6103 \\
\hline & $\mathrm{P} 1$ & $82.42500^{\star}$ & 9.11836 & .000 & 62.9897 & 101.8603 \\
\hline & $\mathrm{P} 2$ & $69.27500^{*}$ & 9.11836 & .000 & 49.8397 & 88.7103 \\
\hline & P3 & $50.65000^{*}$ & 9.11836 & .000 & 31.2147 & 70.0853 \\
\hline & $\mathrm{P} 4$ & & & & & \\
\hline
\end{tabular}

*. The mean difference is significant at the 0.05 level.

Berdasarkan data hasil uji lanjut dengan LSD, terdapat 14 pasang perlakuan yang menunjukkan hasil berbeda secara signifikan. Fakta tersebut diperoleh berdasarkan hasil uji pada kolom Sig. yang kurang dari taraf signifikansi yang telah ditentukan sebesar 0.05. Sisanya, sebanyak 6 pasang perlakuan diketahui tidak memberikan efek yang berbeda secara signifikan. Hasil terbaik diperoleh pada tanaman tomat dengan perlakuan $\mathrm{P}_{4}$ 
yaitu penanaman dengan para para setinggi $100 \mathrm{~cm}$.

Kenapa produksi tomat tertinggi tercapai pada perlakuan $\mathrm{P}_{4}$ yaitu perlakuan dengan memberikan parapara setinggi $100 \mathrm{~cm}$ ?. Karena dengan pemasangan para-para setinggi $100 \mathrm{~cm}$ tanaman tumbuh tegak ke atas, sehingga penyebaran daun dan tunas semakin baik. Semakin baiknya penyebaran daun dan tunas akan menyebabkan sinar terdistribusi semakin merata sehingga memberi peluang semakin banyaknya intensitas cahaya matahari yang dapat diserap oleh tanaman tomat. Cahaya matahari sangat diperlukan dalam proses fotosintesis. Proses fotosintesis merupakan proses pemanfaatan energi cahaya matahari oleh tumbuhan hijau yang terjadi di pigmen klorofil yang terdapat pada organela kloroplas. Kloroplas secara umum terkonsentrasi pada sel-sel jaringan tiang dari daun tanaman. Jadi, fotosintesis merupakan transformasi energi dari energi cahaya matahari dikonversi menjadi energi kimia yang terikat dalam molekul karbohidrat. Proses ini berlangsung melalui reaksi berikut.

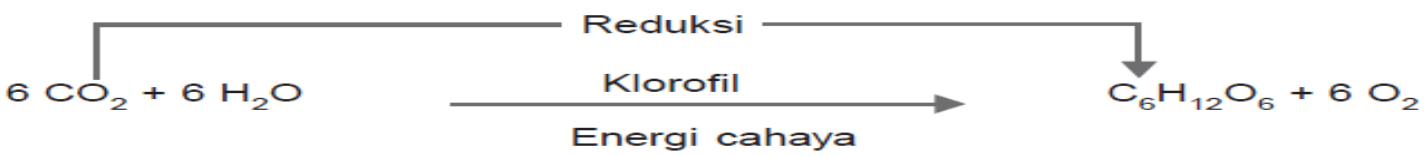

Dalam fotosintesis terjadi tiga macam reaksi yaitu reaksi fisik, reaksi fotokimia, reaksi kimia dan enzim. Pada reaksi fisik, karbón dioksida ditransfer dari atmosfir ke dalam daun untuk dilarutkan dalam air. Pada reaksi fotokimia: $2-4 \%$ radiasi yang diterima digunakan untuk fotosintesis, dengan panjang gelombang yang paling aktif pada bagian sfektrum warna merah dan biru. Pigmen klorofil menyerap lebih banyak cahaya terlihat pada warna biru (400-450 nanometer) dan merah (650700 nanometer) dibandingkan hijau (500-600 nanometer) karena kedua gelombang cahaya tersebut paling efektif dalam fotosintesis. Energi diserap oleh klorofil a dan b (dan beberapa pigmen pembantu) dan diubah oleh molekul klorofil besar menjadi ikatan posfat bernergi tinggi dalam molekul adenosin triphosfat (ATP). Pada reaksi kimia dan enzim terjadi banyak tahapan reaksi kimia dengan penggunaan enzim. ATP dan NADPH yang dihasilkan dalam proses fotosintesis memicu berbagai proses biokimia. Pada tumbuhan proses biokimia yang terpicu adalah siklus
Calvin yang mengikat karbon dioksida untuk membentuk ribulosa (dan kemudian menjadi gula seperti glukosa). Reaksi ini sering disebut dengan reaksi gelap karena tidak bergantung pada ada tidaknya cahaya sehingga dapat terjadi meskipun dalam keadaan gelap/tanpa cahaya.

Kecepatan fotosintesis dipengaruhi oleh faktor tanaman dan lingkungan. Faktor-faktor tanaman meliputi tahap pertumbuhan tanaman, perilaku stomata, umur daun, posisi pohon, posisi tajuk, perbedaan genotipe, dan jenis daun. Adapun faktor lingkungan yang mempengaruhi laju fotosintesis yaitu cahaya, suhu, konsentrasi CO2, ketersediaan air dan nutrisi tanaman. Cahaya merupakan satu-satunya sumber energi yang diperlukan untuk fotosintesis tanaman yang menjadi dasar bagi pertumbuhan dan perkembangan tanamaan tersebut. Intensitas cahaya yang sangat rendah akan sangat merugikan bagi tanaman. Oleh karena itu pemasangan para-para menjadi penting karena para-para memungkinkan tajuk tanaman tersebar 
lebih terbuka sehingga cahaya lebih merata terdistiribusi pada permukaan daun selanjutnya lebih banyak organ tanaman yang menjalankan proses fotosintesis (Nabuanaa, 2016).

Proses pembungaan pada dasarnya merupakan interaksi dari pengaruh dua faktor besar, yaitu faktor eksternal (lingkungan) dan internal. Faktor eksternal (lingkungan) yang berpengaruh antara lain suhu, cahaya, kelembaban dan status unsur hara, sedangkan faktor internal yaitu fitohormon dan genetik. Faktor cahaya berpengaruh terhadap pembungaan melalui dua cara yaitu intensitas cahaya dan fotoperiodisitas (panjang hari). Intensitas cahaya sekali lagi merupakan sumber energi bagi proses pembungaan. Pengurangan intensitas cahaya akan mengurangi inisiasi bunga pada banyak spesies tanaman. Peningkatan intensitas cahaya dengan jalan pemberian para-para akan meningkatkan produksi bunga. Terbukti kuncup bunga lebih banyak terbentuk pada ujung cabang/ranting yang mendapatkan cahaya matahari penuh. Peningkatan produksi bunga secara linier juga meningkatkan produksi buah tanaman tomat. Hal ini diperkuat oleh hasil penelitian yang dilakukan oleh Gama (2017), yang mengatakan bahwa radiasi matahari berdampak pada hasil dan kualitas buah tomat.

Pemasangan para-para setinggi $100 \mathrm{~cm}$ mengakibatkan tanaman tomat lebih tinggi dibandingkan dengan tomat yang diberi para-para setinggi $80 \mathrm{~cm}, 60$ $\mathrm{cm}$ dan $40 \mathrm{~cm}$. Tanaman yang lebih tinggi dapat memberikan hasil per tanaman yang lebih tinggi dibandingkan tanaman yang lebih pendek. Hal ini karena tanaman yang lebih tinggi selain dapat menyerap cahaya lebih banyak juga dapat mempersiapkan organ vegetatifnya lebih baik sehingga fotosintat yang dihasilkan akan lebih banyak (Wasonowati, 2010).
Reformasi pendidikan pada skala nasional sepertinya tidak cukup hanya melakukan program-program khusus dan perubahan kurikulum. Perubahan tersebut seharusnya dimaknai dengan perubahan pemikiran dan komitmen untuk pengembangan diri. Perubahan pemikiran dan sikap tersebut mengacu kepada perubahan paradigma dari bagaimana mengajar ke arah bagaimana belajar dan bagaimana menstimulasi pembelajaran dan learning how to learn. Pengemasan pembelajaran harus didasarkan pada hakikat belajar, hakikat mengajar, hakikat orang yang belajar, dan hakikat orang yang mengajar serta bukan semata-mata berorientasi pada hasil belajar berupa hafalan (rotememorization). Reformasi pendidikan harus diarahkan kepada belajar menurut paradigma konstruktivisme. Menurut paradigma konstruktivisme, pembelajaran yang diterapkan saat ini harus berorientasi pada pembangunan pengetahuan peserta didik secara mandiri. Siswa dilatih untuk menemukan informasi-informasi belajar mandiri dan aktif menciptakan struktur-struktur kognitif dalam interaksi dengan lingkungannya, sehingga terwujud pembelajaran yang berpusat pada siswa (student centered). Salah satu strategi pembelajaran yang baik dan sejalan dengan hakikat konstruktivisme adalah penerapan model pembelajaran berbasis praktikum. Pada pembelajaran berbasis praktikum siswa lebih diarahkan pada experimental learning (belajar berdasarkan pengalaman konkrit), diskusi dengan teman, yang selanjutnya akan diperoleh ide dan konsep baru. Oleh karena itu, belajar dipandang sebagai proses penyusunan pengetahuan dari pengalaman konkrit, aktivitas kolaboratif, dan refleksi serta interpretasi (Haymembat, 2011).

Eksperimen dalam pembelajaran hortikultura dapat membuat mahasiswa belajar mandiri dan dapat memacu mereka untuk memahami konsep biologi 
lebih luas dan mendalam. Hal itu karena mereka mendapat pengalaman dan melakukan percobaan yang memungkinkan mereka menemukan prinsip-prinsip atau pengetahuan bagi dirinya. Dalam melakukan eksperimen tersebut mereka mengumpulkan data atau informasi, menganalisisnya, menemukan jawaban dari permasalahan yang dihadapi dan mampu mengkomunikasikan di depan kelas hasil yang telah mereka peroleh, hingga dapat menarik suatu kesimpulan. Pembelajaran dengan melakukan eksperimen ini dapat dijadikan alternatif pembelajaran bagi dosen pengampu matakuliah hortikultura, karena pembelajaran ini dapat meningkatkan hasil belajar. Exerimental learning sangat sesuai untuk pembelajaran hortikultura, karena mampu memberikan kondisi belajar yang mengembangkan kemampuan berfikir dan kreativitas secara optimal. Hal ini sesuai dengan salah satu capaian pembelajaran matakuliah hortikultura di program studi pendidikan biologi IKIP Saraswati yaitu mahasiswa mampu mengaplikasikan pengetahuan dasar holtikultura dalam bercocok tanam. Dengan ekperimen mahasiswa diberi kesempatan untuk menyusun sendiri konsep dalam struktur kognitifnya, selanjutnya dapat diaplikasikan dalam kehidupannya. Penerapan eksperimen ini akan melahirkan mahasiswa calon guru yang mampu dan menemukan sendiri berbagai jawaban atau persoalan yang dihadapi dengan melakukan percobaan sendiri. Selain itu mahasiswa dapat terlatih dalam cara berfikir yang ilmiah, dengan eksperimen mahasiswa menemukan bukti kebenaran dan teori sesuatu yang sedang dipelajari (Mulyani, 2015)

\section{SIMPULAN}

Berdasarkan hasil analisis data dan pembahasan yang telah dilakukan, dapat disimpulkan sebagai berikut. Terdapat perbedaan yang signifikan antara berat basah buah tomat berdasarkan perlakuan dimana hasil terbaik diperoleh pada tanaman tomat dengan perlakuan $\mathrm{P}_{4}$ yaitu penanaman dengan para-para setinggi $100 \mathrm{~cm}$. Dengan mengimplementasikan penelitian "Pengeruh Tinggi Para-Para Terhadap Produksi Tanaman Tomat (Lycopersicum esculentum Mill)" pada praktikum matakuliah hortikultura maka mahasiswa calon guru mampu dan menemukan sendiri berbagai jawaban atau persoalan yang dihadapi serta menemukan bukti kebenaran dan teori sesuatu yang sedang dipelajari, sehingga potensi dan kreativitas mereka berkembang.

\section{DAFTAR PUSTAKA}

Gama, D.R.D,S; Mesquita, A.C; Yuri, J.E; Ferreira, K.M; Souza, V. 2017. Different Shading Environments Impact Growth And Yield of Three Mini-Tomato Cultivars1. Rev. Caatinga, Mossoró. 30 (2): $324-334$

Longworth, N. 1999. Making life long learning work: Learning cities for a learning century. London: Kogan Page Limited.

Hanafiah, D. \& Suhana, C. 2009. Konsep Strategi Pembelajaran. Bandung: PT Retika Aditama

Haymembat, S.M., Anggaeni, S., Rejeki, S. 2011. Pembelajaran Berbasis Praktikum pada Konsep Invertebrata untuk Pengembangan Sikap IImiah Siswa. Jurnal Bioma (2): 141 152

Mulyani. 2015. Penggunaan Metode Eksperimen Untuk Meningkatkan Hasil Belajar Tentang Rangkaian Listrik Seri dan Paralel Pelajaran Ipa Pada Siswa Kelas Vi Sd Negeri 3 Karanggandu Kecamatan Watulimo Kabupaten Trenggalek. Jurnal Pendidikan Profesional.4 (3): 45-54

Nabuanaa, F.M.G. 2016. Pengaruh Model Ajir dan Pemangkasan 
Tunas Lateral Terhadap Pertumbuhan dan Hasil Tanaman Tomat (Lycopersicum esculentum, Mill.) Cv. Lentana. Savana Cendana Jurnal Pertanian Konservasi Lahan Kering. 1(2): 77-88

Pracaya. 1998. Bertanam Tomat. Yogyakarta: Kanisius.

Rukmana, R.H. 1994. Tomat Chery. Yogjakarta: Kanisius (Anggota IKAPI).

Setiawan dan Trisnawati. 1999. Budidaya Secara Komersial. Jakarta:Penebar Swadaya.

Ogundare, S.K; Babalola, T.S;
Hinmikaiye, A. S. and Oloniruha, J.A. 2015. Growth and Fruit Yield of Tomato as Influenced By Combined Use of Organic and Inorganic Fertilizer In Kabba, Nigeria. European Journal of Agriculture and Forestry Research. 3 (3): 48-56

Wasonowati, C. 2010. Peningkatan Produksi dan Kualitas Tomat (Lycopersicon esculentum) dengan Sistem Budi Daya Hidroponik. Rekayasa. 3 (2): 8389 